\title{
A bibliometric analysis of Acta Pharmaceutica Hungarica (1965-2018)
}

\author{
MÁRIÓ GAJDÁCS* \\ Department of Pharmacodynamics and Biopharmacy, Faculty of Pharmacy, University of Szeged, \\ 6720 Szeged, Eötvös utca 6., Hungary \\ *Corresponding author: Márió Gajdács, mariopharma92@gmail.com
}

Received: 13 January 2019 / Revised: 17 March 2019 / Accepted: 19 March 2019 / Published online: 3 April 2019

\begin{abstract}
:
Aims: The aim of this study is present a general overview of the journal from 1965 to 2018 using bibliometric indicators.

Methods: The data analyzed in this study, was extracted from the Scopus database. The information was exported in RIS file format to the Harzing's Publish or Perish and VOSviewer software for data analysis.

Results: The number of documents published in APH during the study period was 1868, the most frequently published document type was "original article”. Articles published APH were cited 2555 times overall, averaging 1.37 citations per each paper. The highest number of articles published in collaboration was in 2007 and 2018 (16.7\%). Overall, the period between $1981-2000$ was the most fruitful, while the following years saw a decline in the number of articles. Clusters and co-occurrence networks of the authors keyowrds of the published documents were generated.

Conclusion: APH manages to reach a very wide audience of the Hungarian scientific community of researchers. Additionally, an evolution on the research topics covered by the journal could be observed, providing a contemporary overview of the pharmaceutical sciences. The submission of additional articles to the journal is highly encouraged to widen the reach of this journal towards international audiences.
\end{abstract}

Keywords: Acta Pharmaceutica Hungarica, bibliometric analysis, pharmaceutical science, citation, cluster analysis

\section{Introduction}

Acta Pharmaceutica Hungarica (APH) was founded by the Hungarian Society for Pharmaceutical Sciences (MGYT) together with its sister journal, Gyógyszerészet (Pharmacy). While the latter is a monthly publication, which aims to assist pharmacists in education, continuous professional development, highlighting relevant literature and to inform about professional affairs, both in Hungary and on an international scale, APH is quarterly, research-oriented journal, reporting on the experimental results of laboratories involved in pharmaceutical science [1,2]. Bibliometrics is an area of science, which is concerned with the qualitative and quantitative assessment of research, that is often used to evaluate the impact of journals, institutions, study groups or individual scientists $[3,4]$. The bibliometric analysis of a given journal may be important for various reasons; university libraries often evaluate these characteristics before including journals in their collection. Furthermore, authors study commonly known bibliometric parameters (e.g., number of publications per year, impact factor, CiteScore, h-index) before submitting a manuscript to a journal $[5,6]$. Hence, the present study aims to give a general bibliometric overview of APH in a 53-year period (1965-2018), since the journal was listed by international content indexing services.

\section{Materials and methods}

The data analyzed in this study, dating between 1965 and 2018 was extracted from the Scopus database on the $15^{\text {th }}$ of October 2018. The information was exported in RIS (Research Information Systems, Incorporated) file format to the Harzing's Publish or Perish 6.35 software for data analysis $[7,8]$. In addition, VOSviewer 1.6.9 software was used to generate the collaboration and word cooccurrence networks from the recovered data [9].

\section{Results}

The total number of documents published in APH during the study period (1965-2018) was 1868, the number of papers published since 2001 decreased by $46.31-47.11 \%$ compared to the two previous periods (Table I) The most frequently published document type indexed by Scopus was "original article" $(\mathrm{n}=1710,91.54 \%)$, followed by "review" ( $\mathrm{n}=114,6.10 \%$; 
Table I General bibliometric characteristics of APH between 1965-2018

\begin{tabular}{l|c|c|c|c}
\hline \multicolumn{1}{c|}{ Publication years } & $\mathbf{1 9 6 5 - 1 9 8 0}$ & $\mathbf{1 9 8 1 - 2 0 0 0}$ & $\mathbf{2 0 0 1 - 2 0 1 8}$ & Overall \\
\hline Number of papers & $743(39.77 \%)$ & $732(39.19 \%)$ & $393(21.04 \%)$ & 1868 \\
\hline $\begin{array}{l}\text { Citations on the papers during } \\
\text { the study period (1965-2018) }\end{array}$ & $600(23.48 \%)$ & $1463(57.26 \%)$ & $492(19.26 \%)$ & 2555 \\
\hline Cites per year & 11.32 & 39.54 & 28.94 & 48.21 \\
\hline Cites per paper & 0.81 & 2.00 & 1.25 & 1.37 \\
\hline Authors per paper & 2.36 & 3.06 & 3.47 & 2.87 \\
\hline h-index & 8 & 14 & 10 & 14 \\
\hline
\end{tabular}

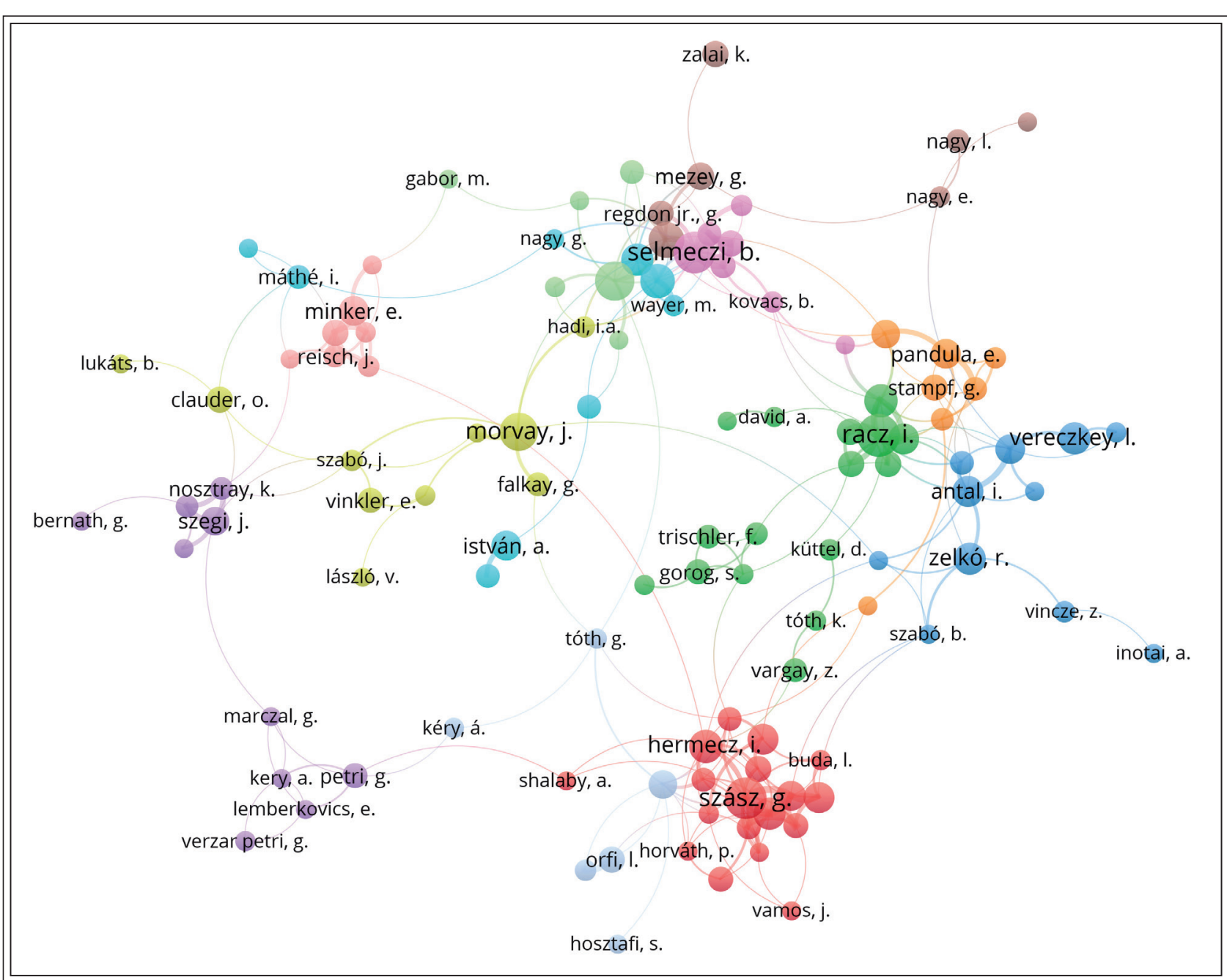

Figure 1 Co-author collaboration network from documents published in APH between 1965-2018

first occurrence in 1991), „short survey" ( $\mathrm{n}=24,1.28 \%$; first occurrence in 1990) and 18 "conference paper" ( $n=18,0.96 \%$; first occurrence in 1989). There was only one paper classified as an „editorial” (in 2011 [10]) and an „erratum” (in 2003), respectively. The average amount of authors per paper increased consistently throughout the years (2.36-3.47; Table I).

Regarding the impact of papers in $\mathrm{APH}$, articles published between 1965 and 2018 were cited 2555 times overall, averaging 1.37 citations per each pa- per, with more than $57 \%$ of overall citations on articles published in the period between 1981-2000. The average ratio of self-citations was $26.76 \%$ (0-69.23\%; highest in 2001). The papers with high amount of citations (defined as 15 or more cites) correspond to $12.13 \%$ of total citations (8.86 citations per year, 140.99 cites/author) for APH (articles listed in Table II). The journal is associated with two subject categories, namely Medicine (miscellaneous) and Pharmaceutical sciences. Based on the in- 


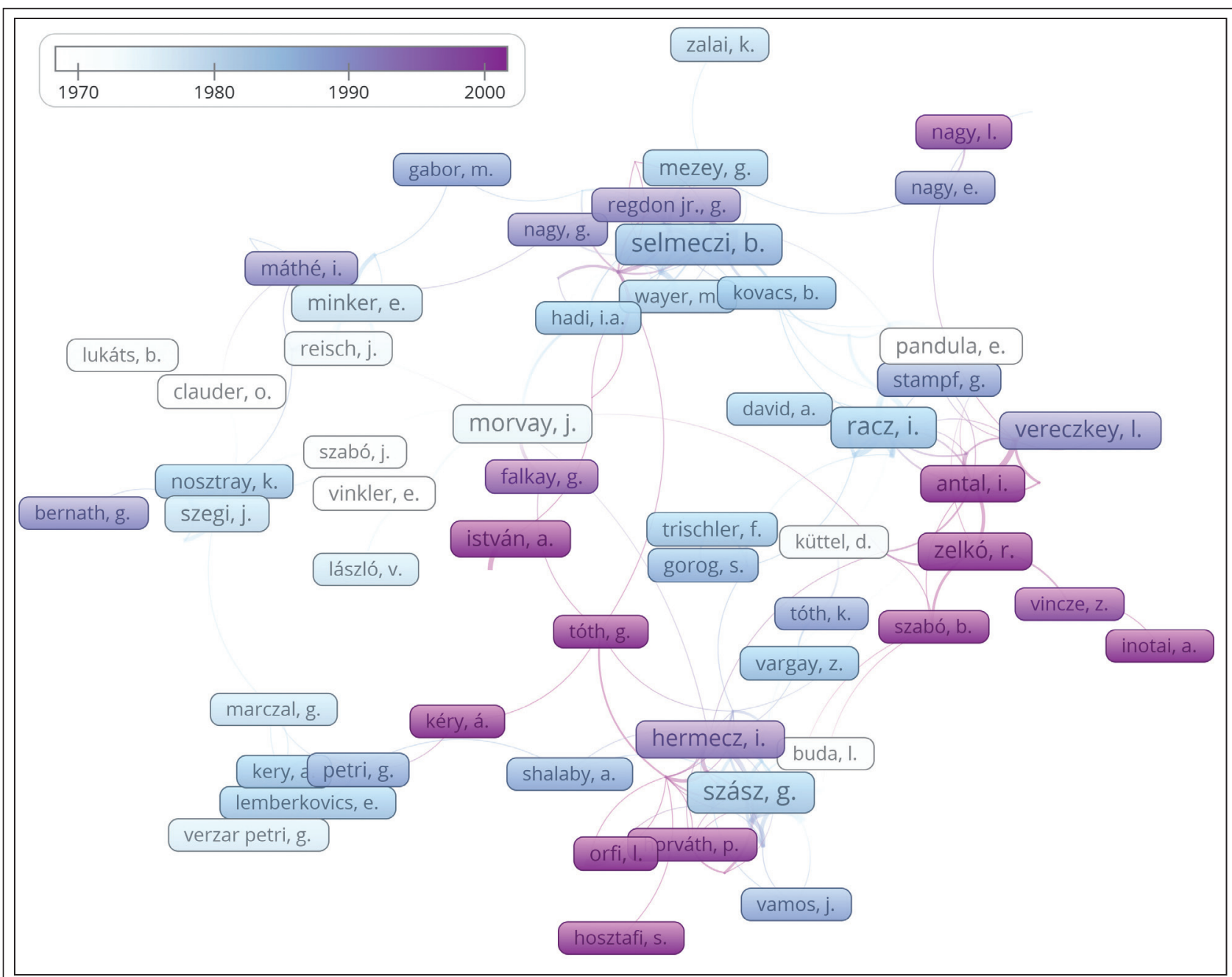

Figure 2 Overlay visualization of co-author collaboration based on year of publication in APH between 1965-2018

ternational impact of the papers published, the quartile ranking of $\mathrm{APH}$ ranged between the second (Q2; 2003) and fourth (Q4; consistently from 2011 onwards) quartile (Table III). International, collaborative research involving multiple partners usually enhances the impact of published articles. For this reason, the ratio of collaborative publications (defined as articles with authors from more than one country) in APH was assessed in the most recent period (2001-2018). Presented in Table IV, the highest number of articles published in collaboration was in 2007 and 2018, respectively ( $16.7 \%$ in both cases).

To establish the network of strong collaborators and the profile of APH in more depth, the authors and the words present in the titles and abstracts of the published documents were analyzed by VOSviewer with the aim of generating clusters and cooccurrence networks. Together with the connecting lines, the colors in Figures 1 and 3 indicate the relationship of the authors and keywords, while in
Figures 2 and 4, the shade of color indicates the temporal nature of relationships.

Out of 2644 authors, 186 met the threshold to become "nodes" in the generated network, while 159 could be included in the network (i.e., had at least one co-authored paper with another author qualifying to be a "node") to generate clusters of association (Figure 1-2). Overall, 7901 keywords were identified by VOSviewer, from which 1164 met the threshold to become "nodes" and 180 was enrolled in the generation of the co-occurrence network (Figure 3-4). Beginning with 1990, the most prevalent keywords were "high performance liquid chromatography", "animal tissue", "human/humans", "drug release", "bioavailability", "drug solubility", "drug manufacture", "plant extract", particle size", "molecular structure", "mass spectrometry" and "nuclear magnetic resonance", reflecting on the changing trends in pharmaceutical sciences in the period of 19802000. 


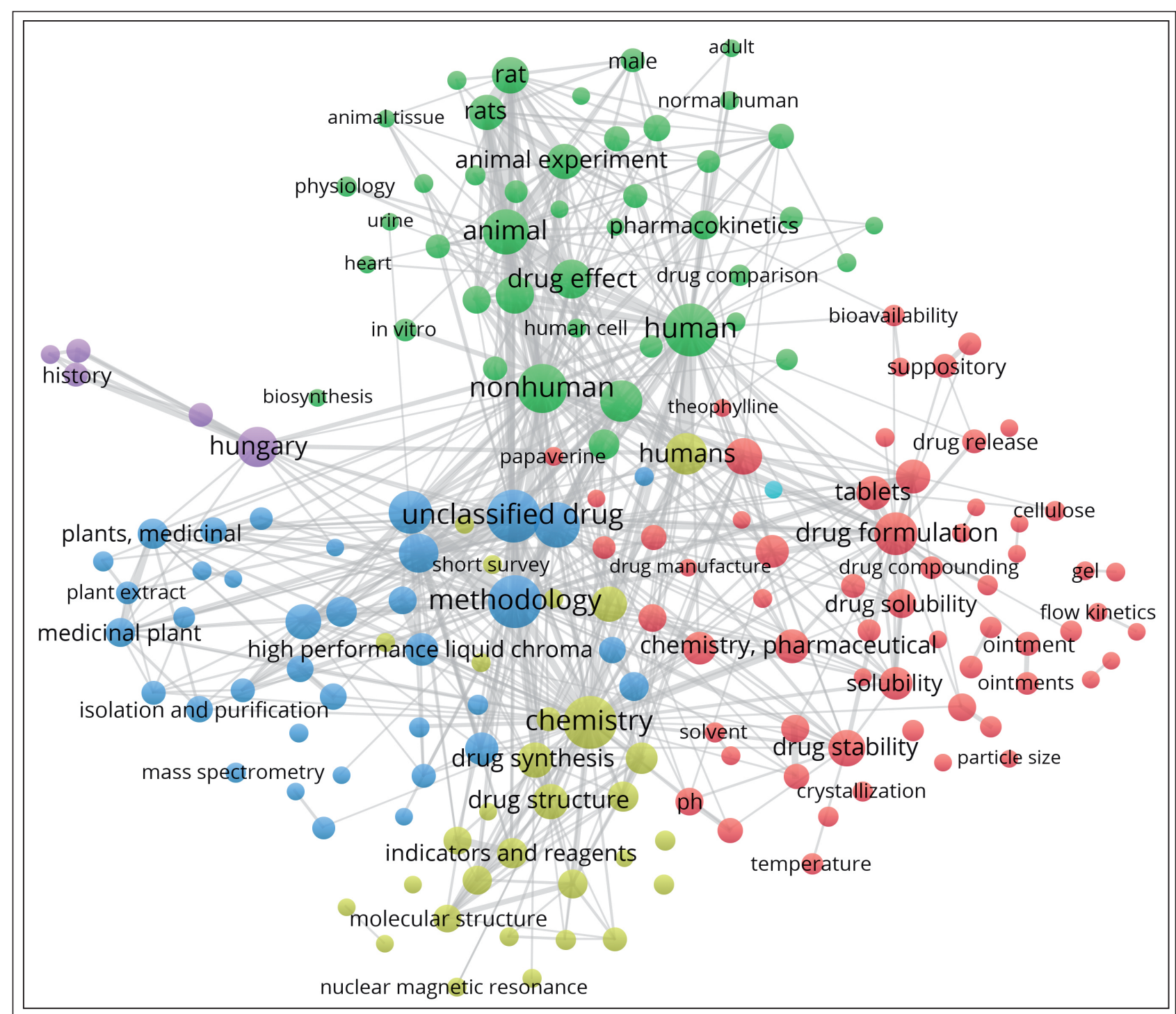

Figure 3 Keyword co-occurrence network from documents published in APH between 1965-2018

\section{Discussion}

The aim of this study was to assess APH using bibliometric methods in the time period between 1965-2018, in which indexing data was available from the Scopus database. From an institutional perspective, most of the papers originated from the four universities in Hungary (Budapest, Debrecen, Pécs and Szeged) where there is a Faculty of Pharmacy or the training of pharmacists takes place. In addition, the Budapest University of Technology (BME) and some industrial institutions (e.g., Gedeon Richter Ltd.) were also important contributors. Citations are generally considered an important parameter to assess the quality of papers published in any given journal, however, the absolute number of citations is not always informative (self-citations or "negative citations" that call attention to flawed papers may distort this bibliometric indicator). The average ratio of self-citations for $\mathrm{APH}$ was $26.76 \%$, which can be considered a good result, compared to other journals published in Hungary. Overall, the 20-year period between 1981-2000 was the most fruitful for this journal, based on the number of published articles and the amount of citations, while the following years between 2001 and 2018 saw a decline in the number of articles by almost $50 \%$ and the number of citations by nearly $300 \%$, whereas the ratio of papers reporting on the research of international collaboration was variable [25-27]. The reason for this decrease may be attributable to the increasing pressure to publish in international journals with (preferably high) impact factors, because this has become a pre-requisite for the awarding of doctoral (PhD) degrees and for successful application for research grants. 
Table II Publications from APH with the most amount of citations

\begin{tabular}{|c|c|c|c|c|}
\hline Publication & Year & Type & Citations & Cites/year \\
\hline $\begin{array}{l}\text { Kiss, B.., Kárpáti, E.: } \\
\text { On the mechanism of action of vinpocetine [11] }\end{array}$ & 1996 & Review & 35 & 1.59 \\
\hline $\begin{array}{l}\text { Fejes, S., Kéry, Á., Blázovics, A., Lugasi, A., Lemberkovics, É., Petri, } \\
\text { G., Szőke, É.: } \\
\text { Investigation of the in vitro antioxidant effect of Petroselinum crispum } \\
\text { (Mill.) Nym. ex A. W. Hill. [12] }\end{array}$ & 1998 & Article & 29 & 1.45 \\
\hline $\begin{array}{l}\text { Medhin, D.G., Hadházy, P., Bakos, P., Verzár-Petri, G.: } \\
\text { Hypotensive effects of Lupinus termis and Coriandrum sativum in anaes- } \\
\text { thetized rats. A preliminary study [13] }\end{array}$ & 1986 & Article & 29 & 0.91 \\
\hline $\begin{array}{l}\text { Matus, Z., Molnár, P., Szabó Gy.: } \\
\text { Main carotenoids in pressed seed (Cucurbitae semen) of oil-pumpkin (Cu- } \\
\text { curbita pepo convar. pepo var. styriaca) [14] }\end{array}$ & 1993 & Article & 26 & 1.04 \\
\hline $\begin{array}{l}\text { Császár, J., Morvay, J.: } \\
\text { Characteristics of Schiff bases derived from salicylaldehyde and sulphon- } \\
\text { amides. Spectral and antibacterial studies [15] }\end{array}$ & 1983 & Article & 25 & 0.71 \\
\hline $\begin{array}{l}\text { Budai, M., Szógyi, M.: } \\
\text { Liposomes as drug carrier systems. Preparation, classification and therapeu- } \\
\text { tical advantages of liposomes [16] }\end{array}$ & 2001 & Article & 23 & 1.35 \\
\hline $\begin{array}{l}\text { Issopoulos, P.B.: } \\
\text { Analytical investigations of } \beta \text {-lactam antibiotics in pharmaceutical prepara- } \\
\text { tions. IV. Sensitive colorimetric determination of five cephalosporins of the } \\
\text { first generation [17] }\end{array}$ & 1991 & Article & 23 & 0.85 \\
\hline $\begin{array}{l}\text { Kéry, A., Horváth, J., Nász, I., Verzár-Petri, G., Kulcsár, G., Dán, P.: } \\
\text { Antiviral alkaloid in Chelidonium majus L. [18] }\end{array}$ & 1987 & Article & 20 & 0.65 \\
\hline $\begin{array}{l}\text { Lemberkovics, É.,, Kéry, Á., Marczal, G., Simándi, B., Szőke, É.: } \\
\text { Phytochemical evaluation of essential oils, medicinal plants and their prepa- } \\
\text { rations [19] }\end{array}$ & 1998 & Short survey & 18 & 0.90 \\
\hline $\begin{array}{l}\text { El-Brashy, A.M.: } \\
\text { Titrimetric determination of captopril in dosage forms [20] }\end{array}$ & 1995 & Article & 18 & 0.78 \\
\hline $\begin{array}{l}\text { Issopoulos, P.B.: } \\
\text { A sensitive spectrophotometric determination of acetaminophen [21] }\end{array}$ & 1992 & Article & 17 & 0.65 \\
\hline $\begin{array}{l}\text { Sarg, T.M., Ateya, A.M., Farrag, N.M., Abbas, F.A.: } \\
\text { Constituents and biological activity of Bidens pilosa L. grown in Egypt [22] }\end{array}$ & 1991 & Article & 16 & 0.59 \\
\hline $\begin{array}{l}\text { Kata, M., Schauer, M.: } \\
\text { Increasing the solubility characteristics of albendazole with dimethyl- } \beta \text { - } \\
\text { cyclodextrin [23] }\end{array}$ & 1991 & Article & 16 & 0.59 \\
\hline $\begin{array}{l}\text { Szántay Cs. Jr., Bihari, M., Brlik, J., Csehi, A., Kassai, A., Aranyi, A.: } \\
\text { Structural elucidation of two novel ergot alkaloid impurities in } \\
\alpha \text {-ergokryptine and bromokryptine [24] }\end{array}$ & 1994 & Article & 15 & 0.63 \\
\hline
\end{tabular}

Table III Quartile ranking of APH between 2001-2018

\begin{tabular}{l|c|c|c|c|c|c|c|c|c}
\hline \multicolumn{1}{c|}{ Category } & $\mathbf{2 0 0 1}$ & $\mathbf{2 0 0 2}$ & $\mathbf{2 0 0 3}$ & $\mathbf{2 0 0 4}$ & $\mathbf{2 0 0 5}$ & $\mathbf{2 0 0 6}$ & $\mathbf{2 0 0 7}$ & $\mathbf{2 0 0 8}$ & $\mathbf{2 0 0 9}$ \\
\hline Medicine (miscellaneous) & $\mathrm{Q} 3$ & $\mathrm{Q} 3$ & $\mathrm{Q} 2$ & $\mathrm{Q} 3$ & $\mathrm{Q} 3$ & $\mathrm{Q} 3$ & $\mathrm{Q} 3$ & $\mathrm{Q} 3$ & $\mathrm{Q} 4$ \\
\hline Pharmaceutical sciences & $\mathrm{Q} 3$ & $\mathrm{Q} 3$ & $\mathrm{Q} 2$ & $\mathrm{Q} 3$ & $\mathrm{Q} 4$ & $\mathrm{Q} 3$ & $\mathrm{Q} 3$ & $\mathrm{Q} 4$ & $\mathrm{Q} 4$ \\
\hline & $\mathbf{2 0 1 0}$ & $\mathbf{2 0 1 1}$ & $\mathbf{2 0 1 2}$ & $\mathbf{2 0 1 3}$ & $\mathbf{2 0 1 4}$ & $\mathbf{2 0 1 5}$ & $\mathbf{2 0 1 6}$ & $\mathbf{2 0 1 7}$ & $\mathbf{2 0 1 8}$ \\
\hline Medicine (miscellaneous) & $\mathrm{Q} 3$ & $\mathrm{Q} 4$ & $\mathrm{Q} 4$ & $\mathrm{Q} 4$ & $\mathrm{Q} 4$ & $\mathrm{Q} 4$ & $\mathrm{Q} 4$ & $\mathrm{Q} 4$ & $\mathrm{Q} 4$ \\
\hline Pharmaceutical sciences & $\mathrm{Q} 3$ & $\mathrm{Q} 4$ & $\mathrm{Q} 4$ & $\mathrm{Q} 4$ & $\mathrm{Q} 4$ & $\mathrm{Q} 3$ & $\mathrm{Q} 4$ & $\mathrm{Q} 4$ & $\mathrm{Q} 4$ \\
\hline
\end{tabular}

Table IV Articles published in international collaboration in APH between 2001-2018

\begin{tabular}{c|c|c|c|c|c|c|c|c|c}
\hline & $\mathbf{2 0 0 1}$ & $\mathbf{2 0 0 2}$ & $\mathbf{2 0 0 3}$ & $\mathbf{2 0 0 4}$ & $\mathbf{2 0 0 5}$ & $\mathbf{2 0 0 6}$ & $\mathbf{2 0 0 7}$ & $\mathbf{2 0 0 8}$ & $\mathbf{2 0 0 9}$ \\
\hline \multirow{3}{*}{ Precentage } & $0 \%$ & $0 \%$ & $6.1 \%$ & $3.7 \%$ & $4.4 \%$ & $8.3 \%$ & $16.7 \%$ & $10.5 \%$ & $5.0 \%$ \\
\cline { 2 - 23 } & $\mathbf{2 0 1 0}$ & $\mathbf{2 0 1 1}$ & $\mathbf{2 0 1 2}$ & $\mathbf{2 0 1 3}$ & $\mathbf{2 0 1 4}$ & $\mathbf{2 0 1 5}$ & $\mathbf{2 0 1 6}$ & $\mathbf{2 0 1 7}$ & $\mathbf{2 0 1 8}$ \\
\cline { 2 - 12 } & $0 \%$ & $6.7 \%$ & $0 \%$ & $6.7 \%$ & $5.6 \%$ & $0 \%$ & $15.8 \%$ & $0 \%$ & $16.7 \%$ \\
\hline
\end{tabular}




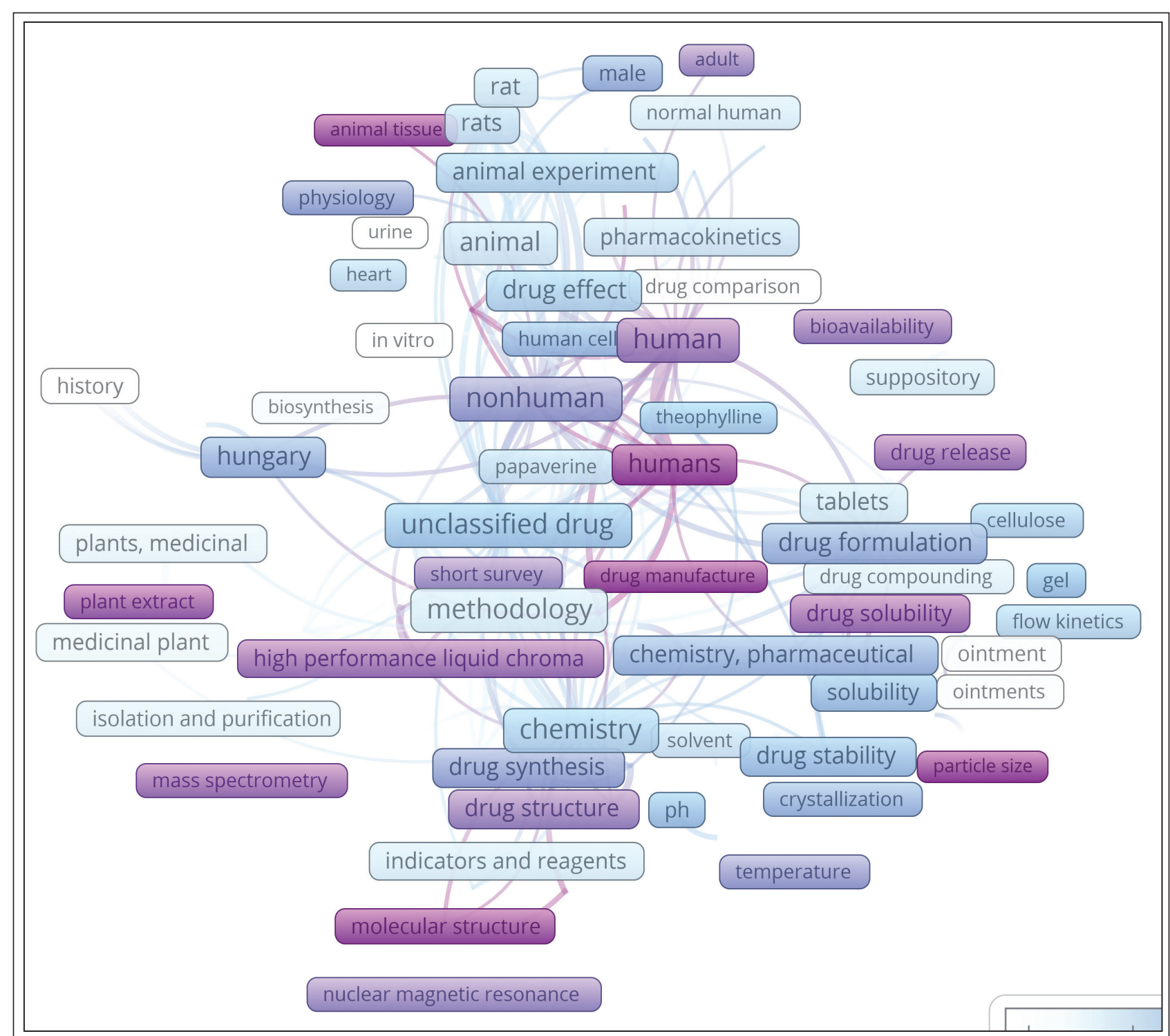

Figure 4 Overlay visualization of keyword co-occurrence based on year of publication in APH between 1965-2018

\section{Conclusions}

This study presents a qualitative and quantitative bibliometric analysis of the leading trends that occurred in the journal between 1965 and 2018, using the Scopus database for the collection of bibliographic information and specialized software for data analysis. To assess APH from a different perspective, this research also presents keyword cooccurrence and collaboration networks of the journal. Acta Pharmaceutica Hungarica manages to reach a very wide audience of the Hungarian scientific community of researchers interested in its content. Additionally, an evolution on the research topics covered by the journal could be observed, providing a contemporary overview of the pharmaceutical sciences. The submission of additional articles to the journal is highly encouraged to widen the reach of this journal towards international audiences.

\section{Acknowledgements}

M.G. was supported by the National Youth Excellence Scholarship [Grant Number NTP-NTFÖ18-C-0225].

\section{References}

1. http://www.mgyt.hu/hu/kiadvanyok/ gyogyszereszet/informaciok [2019.01.04.] Gyógyszerészet: a Magyar Gyógyszerésztudományi Társaság lapja

2. http://www.mgyt.hu/hu/kiadvanyok/actapharmaceutica-hungarica/informaciok [2019.01.04.] Acta Pharmaceutica Hungarica: 
a Magyar Gyógyszerésztudományi Társaság tudományos folyóirata

3. Jain S, Basavaraj P, Singla A, Singh K, Kundu H, Vashishtha $\mathrm{V}$, et al. Bibliometric analysis of journal of clinical and diagnostic research (dentistry section; 2007-2014). J. Clin. Diagn. Res. 2015; 9(4):47-51. https://doi.org/10.7860/JCDR/2015/11994.5834

4. Corrales IE, Reyes JJ, Fornaris Y. Bibliometric analysis of the Journal of Oral Research. Period 2012-2015. 2016; J. Oral Res. 5(5): 188-193. https:// doi.org/10.17126/joralres.2016.042

5. Baladi ZH, Umedani, LV. Pakistan Journal of Medical Sciences: A bibliometric assessment 20012010. 2017; Pak. J. Med. Sci. 33(3): 714-719.

6. Restrepo G, Willett P. The Journal of Mathematical Chemistry: a bibliometric profile J. Math. Chem. 2017; 55(8): 1589-1596. https://doi.org/10.1007/ s10910-017-0747-7

7. Krauskopf, K. A bibiliometric analysis of the Journal of Infection and Public Health: 2008-2016. J. Infect. Pub. Health 2018; 11(2): 224-229. https://doi. org/10.1016/j.jiph.2017.12.011

8. https://harzing.com/resources/publish-or-perish [2019.01.04.] Publish or Perish

9. Alonso S, Cabrerizo FJ, Herrera-Viedma E, Herrera F. h-Index: a review focused in its variants, computation and standardization for different scientific fields. J Informet 2009; 3(4): 273-289. https://doi.org/10.1016/j.joi.2009.04.001

10. Szász G, Noszál B. [László Szabó professor is 80 years old-Greeting]. Acta Pharm. Hung. 2011; 81(1): 3-4.

11. Béla K, Egon K. [On the mechanism of action of vinpocetine]. Acta Pharm. Hung. 1996; 66(5): 213224.

12. Fejes S, Kéry Á, Blázovics A, Lugasi A, Lemberkovics É., Petri G. et al. [Investigation of the in vitro antioxidant effect of Petroselinum crispum (Mill.) Nym. ex A. W. Hill]. Acta Pharm. Hung. 1998; 68(3): 150-156.

13. Medhin DG, Hadházy $P$, Bakos $P$, Verzár-Petri G. [Hypotensive effects of Lupinus termis and Coriandrum sativum in anaesthetized rats. A preliminary study]. Acta Pharm. Hung. 1986; 56(2): 59-63.

14. Matus Z, Molnár P, Szabó Gy. [Main carotenoids in pressed seed (Cucurbitae semen) of oil-pumpkin (Cucurbita pepo convar. pepo var. styriaca)]. Acta Pharm. Hung. 1993; 63(5): 247-256.

15. Császár J, Morvay J. [Characteristics of Schiff bases derived from salicylaldehyde and sulphonamides.
Spectral and antibacterial studies]. Acta Pharm. Hung. 1983; 53(3): 121-128.

16. Budai M, Szogyi M. [Liposomes as drug carrier systems. Preparation, classification and therapeutical advantages of liposomes]. Acta Pharm. Hung. 2001; 71(1): 114-118.

17. Issopoulos PB. [Analytical investigations of $\beta$-lactam antibiotics in pharmaceutical preparations. IV. Sensitive colorimetric determination of five cephalosporins of the first generation]. Acta Pharm. Hung. 1991; 61(2): 205-213.

18. Kéry A, Horváth J, Nász I, Verzár-Petri G, Kulcsár G, Dán P. [Antiviral alkaloid in Chelidonium majus L.]. Acta Pharm. Hung. 1987; 57(1-2): 19-25.

19. Lemberkovics É, Kéry Á, Marczal G, Simándi B, Szőke E. [Phytochemical evaluation of essential oils, medicinal plants and their preparations]. Acta Pharm. Hung. 1998; 68(3): 141-149.

20. El-Brashy AM. [Titrimetric determination of captopril in dosage forms]. Acta Pharm. Hung. 1995; 65(3): 91-93.

21. Issopoulos PB. [A sensitive spectrophotometric determination of acetaminophen]. Acta Pharm. Hung. 1992; 62(1-2), 31-38.

22. Sarg TM, Ateya AM, Farrag NM, Abbas FA. [Constituents and biological activity of Bidens pilosa L. grown in Egypt]. Acta Pharm. Hung. 1991; 61(6): 317-323.

23. Kata, M., Schauer, M. Increasing the solubility characteristics of albendazole with dimethyl- $\beta$ cyclodextrin]. Acta Pharm. Hung. 1991; 61(1): 23-31.

24. Szántay Cs Jr., Bihari M, BrlikJ, Csehi A, KassaiA, Aranyi A. [Structural elucidation of two novel ergot alkaloid impurities in $\alpha$-ergokryptine and bromokryptine]. Acta Pharm. Hung. 1994; 64(3): 105-108.

25. Gajdács M, Handzlik J, Sanmartín C, DomínguezÁlvarez E, Spengler G. [Organoselenium compounds as antitumor agents: in vitro evaluation on a colon cancer model system]. Acta Pharm. Hung. 2018; 88(2): 59-65.

26. Gajdács, M., Handzlik, J., Sanmartín, C., Domínguez-Álvarez, E., Spengler, G. [Prediction of ADME properties for selenocompounds with anticancer and efflux pump inhibitory activity using preliminary computational methods]. Acta Pharm. Hung. 2018; 88(2): 67-74.

27. Gajdács M, Paulik E, Szabó A. [The opinions of community pharmacists related to antibiotic use and resistance]. Acta Pharm. Hung. 2018; 88(43): 249-252. 